\title{
Competitiveness and export development strategy for Indonesia's creative economy sector in the ASEAN market
}

\author{
Haryadi Haryadi*; Etik Umiyati; Sony Tian Dhora
}

Faculty of Economics and Business, Universitas Jambi, Indonesia

*To whom correspondence should be addressed. Email: haryadikamal@gmail.com

\begin{tabular}{|l|l|l|l|l}
\hline DOI: & Received: & Revised: & Accepted: & Published: \\
$10.22437 /$ ppd.v9i2.11832 & 23.01 .2021 & 28.04 .2021 & 18.06 .2021 & 30.06 .2021 \\
\hline
\end{tabular}

\begin{abstract}
The main objectives of this study are (1) to analyze the competitiveness of Indonesian exports in the ASEAN market (2) to formulate a strategy that will be able to support the export competitiveness of Indonesia's creative economy. Revealed Comparative Advantage, Acceleration Ratio, Export Competitiveness Index, and SWOT analysis (to determine a creative economy export development strategy using quantitative) were used as analysis tools. This study focused on examining the subsectors of architecture, movies, animation and video, craft, culinary, music, fashion, publishing, and art. Based on the results, we conclude that all subsectors have export competitiveness in the ASEAN market. Among them, craft and culinary appear as subsectors with strong competitiveness and meet all the analysis criteria. The results also show that SO strategy (growth) could be chosen to develop the creative economy.
\end{abstract}

Keywords: ASEAN, Creative economy, Export competitiveness, SWOT analysis

JEL Classification: L53, M21, O10

\section{INTRODUCTION}

Economic growth is one of the most important indicators in measuring the national economy of a country. Exports are one indicator that can be used to trigger economic growth. Salvatore (2014) states that exports can be an engine of growth. Many studies prove that exports have become an essential part of the government's efforts to spur economic growth (Nushiwat, 2008; Sumiarty, 2015; Ibrahim \& Abdalla, 2020; Kollie, 2020; Akter \& Bulbul, 2017; Athanasia \& Trevor, 2020, Kim et al. 2020; Adelakun \& Olayiwola, 2020; Herzer, 2010; Sannassee et al. 2014)

Indonesia is one of the countries that continue to encourage exports. Historically, until 1986, Indonesia still relied on its exports to the oil sector. This is a phenomenon in Indonesia. Due to the downward trend in oil prices, Indonesia has changed its export orientation to non-oil and gas exports. Since 1987, Indonesia's exports were dominated by non-oil and gas exports.

Theoretically, the development of exports is affected by various factors, both domestic and overseas. From 2010 to 2015, Indonesia's non-oil and gas exports continuously declined (BPS, 2016). Some of the influencing factors include the economic crisis in America and Europe, unstable global market conditions, and increased production costs due to price increases that are thought to have contributed to the decline in non-oil and gas exports. 
To overcome the decline of exports, the Indonesian government has launched a breakthrough by encouraging the creative industry to appear as a mainstay of Indonesian exports. The government has launched "a Creative Economy Program". The program is expected to become "a backbone" of the Indonesian economy. Unlike other highly dependent sectors on natural resource exploitation, creative economy rests on human resources optimization. The creative economy is believed to positively impact forming the new image and identity of the nation, increasing competitive advantage, and providing a positive social impact (Agung, 2014).

The development of an export-based creative economy, as well as the human resource based on science and technology, has great potential to encourage the regrowth of the Indonesian economy (Maimuna, 2017). Exports creative economy showed an increase from year on year (Table 1). During the period 2010 to 2015, the export value of the creative economy continued to increase. The largest increase occurred in 2014, amounting to US \$19,364 million (Romarina, 2016).

The role of the creative economy in Indonesia's non-oil and gas exports is very promising. During this period, Indonesia's total exports grew by an average of $11.56 \%$ and $9.63 \%$, respectively. These encouraging conditions will continue into 2020. In the first quarter, creative industry exports have grown by 17.05 percent (Subagja, 2017). This development is expected to offset the decline in the export contribution of other commodities that have shown a relative decline during the era of the COVID-19 pandemic (BEKRAF, 2020).

Table 1. The export value of the Indonesian creative economy and Indonesia total exports in 2010- 2015

\begin{tabular}{llrrrrrr}
\hline Description & & 2010 & 2011 & 2012 & 2013 & 2014 & 2015 \\
\hline \multirow{2}{*}{ Export value } & Ecraf (million US \$) & 13507 & 15641 & 15840 & 15871 & 18165 & 19364 \\
& Total exports (sales of US \$) & 157779 & 203497 & 190020 & 182551 & 175980 & 150366 \\
\hline \multirow{2}{*}{ Craft Export } & For non-oil exports (\%) & 10.41 & 9.65 & 10.09 & 10.59 & 12.45 & 14.69 \\
& For Export Total (\%) & 8.56 & 7.69 & 8.13 & 8.69 & 10.32 & 12.88 \\
\hline Changes in & Ecraft (\%) & - & 15.8 & -1.29 & 2,79 & 14.46 & 6.6 \\
Exports & Total Exports (\%) & - & 28.98 & -6.62 & -3.93 & -3.6 & -14.55 \\
\hline \multicolumn{2}{l}{ Source: BEKRAF and BPS. (2017) } & & & & & &
\end{tabular}

The creative economy industry does not have a singular definition. The concept will continue to develop as long as there is an interaction between human creativity and intellectual, knowledge and technology. The question that appeared is "what can be the determining factor in increasing human creativity in the creative economy?". One of the factors affecting the export is competitiveness. This is becoming increasingly important considering the competition in the international market, including the ASEAN market, will be tighter.

ASEAN Economic Community (AEC) can threaten business actors if an increase in competitiveness does not accompany it. Moreover, the Indonesian market could also come under attack from foreign products. This will also cause high competition in the creative economy trade in the future. This topic is important to discuss so that the export of creative industries can become one of the mainstays of Indonesia's exports. The main objectives of this study are (1) to analyze the development of exports of the creative economy in the ASEAN market, competitive conditions, and the position of creative economy subsectors Indonesia, (2) to formulate a strategy that will be able to support the export competitiveness of Indonesia's creative economy.

\section{LITERATURE REVIEW}

As a variable forming GDP, exports occupy an important position in the national economy (Haryadi, 2014). countries in the world in an open economy rely heavily on 
exports to improve the economy (Zuhdi \& Suharno, 2015). Greenaway et al. (1999) examined the relationship between exports and economic growth of 69 developing countries. The results showed that there is a positive relationship between total exports and economic growth.

Various kinds of literature state that the foreign exchange rate, inflation, GDP of the destination country, the income of the destination country. Apart from these factors, government policies are also very much needed. In other literary sources, it is also stated that to encourage exports, a country must have competitiveness, and its products must have advantages compared to products of other countries. With these advantages, domestic products will be able to compete with products from other countries. Research by Amalia \& Firdaus (2014), Fadhlan \& Suharno (2015), Purnamasari et al. (2014). Polnaya \& Darwanto (2015) prove that competitiveness has a positive effect on a country's exports.

The discussion regarding the concept of competitiveness cannot be separated from the evolution of the competitiveness theory itself. At first, the theory of competitiveness specifically discusses the ability of a company to survive in a dynamic market. The theory of competitiveness at the company level in a country develops into a competitiveness concept between countries. According to Heckscher-Ohlin (Haryadi, 2014), the factors of production that are generally categorized as land, labor, and capital are too general to show competitive advantages in the strategies of different industries. Another competitiveness theory is Porter's theory of competitive advantage. Porter \& Ramirez-Vallejo (2017) stated that comparative advantage could be found at the company and national levels. There are four things in building the advantages of a country described by Porter as a diamond-shaped scheme, namely the condition of factors such as skilled personnel and infrastructure, conditions of domestic demand and quality demands for certain industrial products, the existence of competitive and supporting competitive industries, and strategy, structure, and competition between companies. In addition, there is a significant correlation with the variable role of government in creating a competitive advantage.

A strategy is needed to develop competitiveness. The SWOT (StrengthWeakness-Opportunity-Thread) matrix can be used as a tool to determine strategies in developing competitiveness. This matrix is an important matching tool to help managers develop four strategies (Purwanto, 2008). The types of strategies referred to are: 1). SO (Strengths Opportunities) strategy is a strategy that the company uses by utilizing or optimizing its strengths (S) to take advantage of various opportunities / Opportunities (O). 2). WO (Weaknesses Opportunities) strategy is a strategy that the company uses to minimize the existing weaknesses / Weaknesses (W) to take advantage of opportunities/Opportunities (O). 3). ST (Strengths Threats) strategy is a strategy that companies use by utilizing or optimizing their Strengths (S) to reduce the various threats / Threats (T) that may surround the company. 4). WT (Weaknesses Threats) strategy is a strategy used to reduce weaknesses (W) to minimize or avoid threats / Threats (T).

Furthermore, Howkins (2001) stated that the emergence of a new economic wave based on creativity after seeing in 1997 the United States produced US \$ 414 billion worth of Intellectual Property Rights (IPR) products, making IPR the number one export item in the United States. In Indonesia itself, the development of the creative economy began in 2006 when President Susilo Bambang Yudhoyono instructed the sector's development (Dellyana et al. (2015).

This development process was first manifested by establishing the Indonesian Design Power by the Ministry of Trade to help develop the creative economy in Indonesia. In 2007, the Indonesian Creative Industry Contribution Mapping Study was 
launched at the Indonesia Trade Expo. This success then results in the establishment of BEKRAF by President Joko Widodo in 2015 (Rambatan, 2015). The creative economy in Indonesia is currently in the spotlight because it contributes significantly to the economy in Indonesia. Based on BEKRAF data, the contribution of the creative economy to Indonesia's 2017 gross domestic product is $7.28 \%$.

\section{METHODS}

This study uses secondary data (time series data). Those data are obtained from Ekraf (Creative Economy Bureau), the United Nations Commodity and Trade Database (UNComtrade), and the previous studies 2010-2019.

To gauge a level of competitiveness, Revealed Competitive Advantage (RCA) had been used. The greater the coefficient of the RCA index for a commodity, the stronger its competitiveness. It means that these subsectors are feasible to be developed, or the country must specialize in the sub-sectors to compete in the ASEAN market. The formula used is:

RCA index $=\frac{X i j / A_{i}}{X_{t j} / A t}$

Where: $\mathrm{Xij}=$ The value of exports subsector $\mathrm{i} \mathrm{j}$ countries to the ASEAN market

$\mathrm{X}_{\mathrm{tj}}=\mathrm{j}$ country's total export value to ASEAN market

$\mathrm{Ai}=$ Value of ASEAN exports to the sub-sector $\mathrm{i}$

At $=$ total export value of ASEAN

$\mathrm{i}=$ Subsector studied creative economy

To measure the seize of the market, we use the formula namely (AR). If $A R$ is close to or more than one, it means that the subsector of these countries can size the market. Vice versa, if AR is less than zero or close to -1 , it means nothing to grab market share suppliers so that the state can not seize the market (Muslim, 2006). Mathematically, AR can be formulated as follows:

$\mathrm{AR}=\frac{\text { Trend } X i j+100}{\text { Trend } X i b+100}$

Where: $\mathrm{Xij}=$ Value of export subsectors $\mathrm{i}$ country $\mathrm{j}$ into ASEAN market

$\mathrm{Xib}=$ Value of ASEAN exports to the sub-sector $\mathrm{i}$

$\mathrm{i}=$ Subsector studied creative economy

Analysis of export competitiveness index (ECI) has been used in measuring a trend of competitiveness. If the value of ECI is a subsector is greater than one (the value of ECI> 1), the sub-sector is facing an increasing competitiveness trend in the ASEAN market, whereas if the value is smaller than the ECI (ECI value <1) (Muslim,2006). ECI can be formulated as follows:

$\mathrm{ECI}=\frac{\left(\frac{X i j}{A i}\right) t}{\left(\frac{X i j}{A t}\right) t-1}$

Where: $\mathrm{Xij}=$ The value of exports subsector $\mathrm{i}$ countries $\mathrm{j}$ to the ASEAN market

$\mathrm{Ai}=$ Value of ASEAN exports to the sub-sector $\mathrm{i}$

$\mathrm{t}=$ Year 2010-2015

$\mathrm{t}-1=$ previous year

$\mathrm{i}=$ Subsector studied creative economy

The results of the three analyzes will be grouped into two categories (subsectors are competitive and not competitive). 
Table 2. Grouping matrix subsector creative economy competitiveness

\begin{tabular}{|c|c|c|c|}
\hline \multicolumn{3}{|c|}{ Criteria } & \multirow{2}{*}{ Criterion } \\
\hline $\mathrm{RCA}$ & $\mathrm{AR}$ & ECI & \\
\hline More than 1 & More than 0 & More than 1 & Competitive Strong \\
\hline More than 1 & More than 0 & Less than 1 & Competitive \\
\hline More than 1 & Less than 0 & More than 1 & Competitive \\
\hline Less than 1 & More than 0 & More than 1 & Competitive \\
\hline More than 1 & Less than 0 & Less than 1 & Not Competitive \\
\hline Less than 1 & More than 0 & Less than 1 & Not Competitive \\
\hline Less than 1 & Less than 0 & More than 1 & Not Competitive \\
\hline Less than 1 & Less than 0 & Less than 1 & Very Not Competitive \\
\hline
\end{tabular}

\section{Analysis strengths, weaknesses, opportunities, threats (SWOT)}

SWOT analysis is used to identify various factors that systematically formulate a company's strategy to be able to compare external factors, opportunities, and threats to the strengths and weaknesses of internal factors. Internal and external factors are included in the IFAS and EFAS matrices (Rangkuti, 2016). After the matrix of internal factors and external strategies is completed, the creative economy can be developed quantitatively through SWOT analysis calculations.

The calculation is carried out in several stages, namely:

1. Give each factor weight in column a, from 1.0 (very important) to 0.0 (not important). The way to determine the weight of each indicator from internal and external factors is by using a priority scale starting from 4 (very important), 3 (important), 4 (quite important), and 1 (not important) on positive variables. In contrast, the negative variables were given the opposite value, namely 1 (very important), 2 (important), 3 (quite important), and 4 (not important). Then multiply the value of the priority scale (SP) by a constant (K). The determination of the constant value is based on the highest value, which is 4 , with the assumption that all indicators are considered good. Each value of SP $\mathrm{x} \mathrm{K}$ is divided by the total value of SP $x$ K to get the weighted value.

2. Give a rating (in column b) for each factor by giving a scale ranging from 4 (very good) to 1 (below average). The rating for the strength and opportunity factor is positive (the greater the strength and opportunity is rated 4, but if the strength and opportunity are small, it is rated 1). Weakness and threat rankings are the opposite. For example, if the score for weaknesses and threats is very high, then the rating is 1 , and if the weaknesses and threats are low, then the rating is 4 .

3. Multiply the weight in column a by the rating in column b to get a score (c) for each factor.

4. By subtracting the number of factors $\mathrm{S}$ and $\mathrm{W}$ and factors $\mathrm{O}$ and $\mathrm{T}$, the resulting difference between factors $\mathrm{S}$ and $\mathrm{W}$ then becomes a value or point on the $\mathrm{X}$-axis. At the same time, the difference between factors $\mathrm{O}$ and $\mathrm{T}$ becomes a value or point on the Y-axis.

5. Look for the creative economy sector position indicated by dots $(x, y)$ in the SWOT quadrant/diagram as a strategy determination.

\section{RESULTS AND DISCUSSION}

The competitiveness of creative economy subsectors Indonesia in the ASEAN market

Table 3 shows that all sub-sectors meet the criteria for being a competitive sector. However, among all sectors, craft and culinary meet the criteria as a strong competitive 
creative industry. This indication is shown by fulfilling the three analysis criteria (RCA, AR, and ECI). This finding is in line with Rosnawintang (2015), which states that the Indonesian food and beverage industry products have a level of competitiveness that tends to fluctuate, bread and cake products have the highest competitiveness, the highest competitiveness value of these products is in Vietnam. Based on these findings, this commodity is very necessary and is a top priority that needs to be developed in the ASEAN market. Meanwhile, architecture, film, animation, and video, music, fashion, publishing, and fine arts meet only two of the three competitiveness criteria. This group still needs to be developed but occupies the second priority to be developed.

Table 3. Grouping matrix of the subsector of Indonesian creative economy competitiveness in the ASEAN Market

\begin{tabular}{|c|c|c|c|c|c|}
\hline No. & subsector & RCA & AR & ECI & Criteria \\
\hline \multirow{2}{*}{1} & \multirow{2}{*}{ Architecture } & 0.940 & 0.922 & 3.027 & \multirow{2}{*}{ Competitive } \\
\hline & & Less than 1 & More than 0 & More than 1 & \\
\hline \multirow{2}{*}{2} & \multirow{2}{*}{$\begin{array}{l}\text { Film, Animation } \\
\text { and Video }\end{array}$} & 0,017 & 3.404 & 2.791 & \multirow{2}{*}{ Competitive } \\
\hline & & Less than 1 & More than 0 & More than 1 & \\
\hline \multirow{2}{*}{3} & \multirow{2}{*}{ Craft } & 1.49 & 1.097 & 1.109 & \multirow{2}{*}{$\begin{array}{l}\text { Competitive } \\
\text { Strong }\end{array}$} \\
\hline & & More than 1 & More than 0 & More than 1 & \\
\hline \multirow{2}{*}{4} & \multirow{2}{*}{ Culinary } & 1.335 & 1.073 & 1,071 & \multirow{2}{*}{$\begin{array}{l}\text { Competitive } \\
\text { Strong }\end{array}$} \\
\hline & & More than 1 & More than 0 & More than 1 & \\
\hline \multirow{2}{*}{5} & \multirow{2}{*}{ Music } & 0.023 & 1.267 & 1.222 & \multirow{2}{*}{ Competitive } \\
\hline & & Less than 1 & More than 0 & More than 1 & \\
\hline \multirow{2}{*}{6} & \multirow{2}{*}{ Fashion } & 2.295 & 0.964 & 0.965 & \multirow{2}{*}{ Competitive } \\
\hline & & More than 1 & More than 0 & Less than 1 & \\
\hline \multirow{2}{*}{7} & \multirow{2}{*}{ Publishing } & 0.205 & 1,287 & 1.292 & \multirow{2}{*}{ Competitive } \\
\hline & & Less than 1 & More than 0 & More than 1 & \\
\hline \multirow{2}{*}{8} & \multirow{2}{*}{ Art } & 1.196 & 0.926 & 0.936 & \multirow{2}{*}{ Competitive } \\
\hline & & More than 1 & More than 0 & Less than 1 & \\
\hline
\end{tabular}

Source: UNComtrade (processed), 2017

\section{Prioritization strategies that support the export competitiveness of the creative economy sector}

Mapping priority creative economy development strategies in Indonesia to support the increased competitiveness of exports is carried out by using factor analysis of the Internal and External Factors, namely IFAS and EFAS. Once the internal and external strategy matrix is finalized, the creative economy can be developed quantitatively through calculation Quantitative SWOT analysis.

Table 4 shows the results of determining the weight of the internal factors of the creative economy. As shown in Table 4, abundant natural resources and local raw materials have the highest weight because these factors are a priority scale for the development of the creative economy. It means that this subsector is a very important force in advancing the creative economy. Meanwhile, the biggest weaknesses in the creative economy are: there is still an assumption that the creative economy sector is not a promising place to work, and there is still weak product design both in terms of quantity and quality. 
Table 4. Determining the weight of internal factors of the creative economy

\begin{tabular}{|c|c|c|c|c|c|}
\hline \multirow[b]{2}{*}{ No. } & Internal factors & \multirow{2}{*}{$\begin{array}{l}\text { Scale } \\
\text { Priority } \\
\text { (SP) }\end{array}$} & \multirow{2}{*}{$\begin{array}{c}\text { Cons- } \\
\text { tants } \\
(\mathrm{K})\end{array}$} & \multirow{2}{*}{ SP x K } & \multirow{2}{*}{ Weight } \\
\hline & Strength & & & & \\
\hline 1 & Potential residents and population & 3 & 4 & 12 & 0.10 \\
\hline 2 & Rich culture and heritage & 3 & 4 & 12 & 0.10 \\
\hline 3 & Abundant natural resources and attractive & 4 & 4 & 16 & 0.13 \\
\hline 4 & Creative economy in all regions of the country & 3 & 4 & 12 & 0.10 \\
\hline 5 & $\begin{array}{l}\text { Most creative industrial raw materials instead of imported, } \\
\text { but it comes from a local }\end{array}$ & 4 & 4 & 16 & 0.13 \\
\hline No. & Weakness & & & & \\
\hline 1 & $\begin{array}{l}\text { Weak in product design, both in number and quality of job } \\
\text { design }\end{array}$ & 3 & 4 & 12 & 0.10 \\
\hline 2 & Weak in product commercialization & 2 & 4 & 8 & 0.07 \\
\hline 3 & $\begin{array}{l}\text { Lack of understanding of the production and business } \\
\text { management }\end{array}$ & 2 & 4 & 8 & 0.07 \\
\hline 4 & Work ethic and productivity are still lacking & 1 & 4 & 4 & 0.03 \\
\hline 5 & $\begin{array}{l}\text { Considers that the creative economy is not the place } \\
\text { promising career }\end{array}$ & 4 & 4 & 16 & 0.13 \\
\hline 6 & $\begin{array}{l}\text { Lack of creative economy development movement that } \\
\text { touches the lower level and a new stage of discourse }\end{array}$ & 1 & 4 & 4 & 0.03 \\
\hline & Total SP x K & & & 120 & 1.00 \\
\hline
\end{tabular}

Table 5 shows the simulation results of calculations using the creative economy subsector IFAS matrix. From Table 5, it can be seen that the score for the strength factor is 1.78 , and the score for the weakness factor is 0.60 . Based on this table, it can be interpreted that the strengths in the development of Indonesia's creative economy are higher than the weaknesses they have. Quantitatively, the difference is 1.18.

Table 5. Internal matrix factor analysis summary (IFAs) sectors of the creative economy

\begin{tabular}{clrcc}
\hline & Internal factors & Weight & rating & Score \\
\hline No & Strength & 0.10 & 4 & 0.4 \\
\hline 1 & Potential residents and population & 0.10 & 3 & 0.3 \\
2 & Rich culture and heritage & 0.13 & 4 & 0.52 \\
3 & Abundant natural resources and attractive & 0.10 & 3 & 0.30 \\
4 & Creative industries are scattered in various regions of the country & 0.13 & 2 & 0.26 \\
\hline & Most creative industrial raw materials instead of imported, but it & & & 1.78 \\
\hline & comes from a local & & & 0.10 \\
\hline No & Weakness & 0.10 & 1 & 0.14 \\
\hline 1 & Weak in product design, both in number and quality of job design & 0.07 & 2 & 0.14 \\
2 & Weak in product commercialization & 0.07 & 2 & 0.03 \\
3 & Lack of understanding of the production and business management & 0.03 & 1 & 0.13 \\
4 & Work ethic and productivity are still lacking & 0.13 & 1 & 0.06 \\
5 & Considers that the creative economy is not the place promising career & 0.03 & 2 & 0.60 \\
\hline 6 & Lack of creative economy development movement that touches the & & & 0.18 \\
\hline & lower level and a new stage of discourse & & & 1.13 \\
\hline & Dotal & & & \\
\hline
\end{tabular}

Table 6 shows the results of determining the weight of the creative economy internal factors. As shown in Table 6, the growing trend in creative economy outcomes has the highest weighting score $(0.18)$, followed by market share and consumer expectations, with each weighting 0.14 . This means that the opportunity to develop the creative economy more than this sub-sector is a very important force in advancing the creative economy. Meanwhile, the biggest weakness of the creative economy is the assumption that the creative economy sector is not a promising place to work, and the product design is still weak in terms of quantity and quality. 
Table 6. External factors determining weights creative economy

\begin{tabular}{|c|c|c|c|c|c|}
\hline & External Factors & Scale & & & \\
\hline No. & Opportunities & $\begin{array}{l}\text { Priority } \\
\text { (SP) }\end{array}$ & (K) & SP x K & Weight \\
\hline 1 & $\begin{array}{l}\text { The market share of the results of the creative } \\
\text { economy, both locally, nationally, and } \\
\text { globally is likely to increase }\end{array}$ & 4 & 4 & 12 & 0.14 \\
\hline 2 & $\begin{array}{l}\text { There is a growing tendency enthuses } \\
\text { creative economy outcomes }\end{array}$ & 4 & 4 & 16 & 0.18 \\
\hline 3 & $\begin{array}{l}\text { Consumer expectations towards creative } \\
\text { economy higher product }\end{array}$ & 3 & 4 & 12 & 0.14 \\
\hline 4 & $\begin{array}{l}\text { Backed by their colleges in the provision of } \\
\text { quality human resources and appropriate } \\
\text { industry needs }\end{array}$ & 2 & 4 & 8 & 0.09 \\
\hline No. & Threats & & & & \\
\hline 1 & $\begin{array}{l}\text { Globalization and free trade that requires } \\
\text { high competitiveness }\end{array}$ & 1 & 4 & 4 & 0.05 \\
\hline 2 & $\begin{array}{l}\text { Increasing competition of foreign products } \\
\text { and the number of competitors }\end{array}$ & 1 & 4 & 4 & 0.05 \\
\hline 3 & $\begin{array}{l}\text { the quality of competitors' products is } \\
\text { relatively higher because it uses technology } \\
\text { devices }\end{array}$ & 2 & 4 & 8 & 0.09 \\
\hline 4 & Technology advances faster & 3 & 4 & 12 & 0.14 \\
\hline 5 & $\begin{array}{l}\text { Less enthuses domestic product by the } \\
\text { majority of society }\end{array}$ & 3 & 4 & 12 & 0.14 \\
\hline \multicolumn{4}{|c|}{ Total SP x K } & 88 & 1.00 \\
\hline
\end{tabular}

Based on Table 7, it can be seen that the value for the sub-sector opportunity is 1.97, while the value for the threat sector is 1.31 . This means that there is a difference between the two sectors 1.31. According to Rangkuti (2019), the industry has responded to the opportunities around it by avoiding threats in its industrial market. Lestariningsih et al. (2017) three dimensions in sustainable development include economic growth, social development, and environmental sustainability. The development of creative industries make a positive contribution to the business climate, the creation of innovation, and the formation of creativity which is supported in terms of (1) HR as the basic capital, (2) Industry, (3) Technology, (4) Resources, (5) Institutions, and (6) Financial institutions. In addition, the role of business and the role of government is very much needed to support and develop the creative industry in MSMEs. It can be said that the opportunities for economic development are greater than that of the region

.Table 7. Matrix external factor analysis summary (EFAS) sectors of the creative economy

\begin{tabular}{|c|c|c|c|c|}
\hline & External Factors & Weight & rating & Score \\
\hline No & Opportunities (Opportunities) & weignt & ratung & score \\
\hline 1 & $\begin{array}{l}\text { The market share of the results of the creative economy, both locally, } \\
\text { nationally, and globally, tend to rises }\end{array}$ & 0.14 & 4 & 0.56 \\
\hline 2 & There is a growing tendency enthuses creative economy outcomes & 0.18 & 4 & 0.72 \\
\hline 3 & Consumer expectations towards creative economy higher product & 0.14 & 3 & 0.42 \\
\hline 4 & $\begin{array}{l}\text { Backed by their colleges in the provision of quality human resources and } \\
\text { appropriate industry needs }\end{array}$ & 0.09 & 3 & 0.27 \\
\hline & Total & & & 1.97 \\
\hline Nc & Threats (Threats) & & & \\
\hline 1 & Globalization and free trade that requires high competitiveness & 0.05 & 2 & 0.10 \\
\hline 2 & Increasing competition of foreign products and the number of competitors & 0.05 & 1 & 0.05 \\
\hline 3 & $\begin{array}{l}\text { The quality of competitors' products is relatively higher because it uses } \\
\text { technology devices }\end{array}$ & 0.09 & 1 & 0.09 \\
\hline 4 & Technology advances faster & 0.14 & 2 & 0.28 \\
\hline 5 & Less enthuses domestic product by the majority of society & 0.14 & 1 & 0.14 \\
\hline & Total & & & 0.66 \\
\hline & Difference Total Total Opportunities with Threats & & & 1.31 \\
\hline
\end{tabular}


Based on identifying these factors and determining the difference in scores, it can be seen that IFAS and EFAS are positive. Syarif et al. (2015) stated that this indicator is very useful for knowing profitable opportunities and strategies to take advantage of existing opportunities. The strategy that must be applied in this condition is to support an aggressive growth policy. These results are then depicted in the SWOT diagram, where the strength and opportunity factors are given a positive value $(+)$. At the same time, the weakness and threat factors are given a positive value $(+)$. The diagram is presented in Figure 1.

Based on the Cartesian SWOT diagram presented in Figure 1, the creative economy sector is located in the first quadrant. It is meaning that the creative economy development strategy is the SO strategy, namely the strategy of using all strengths to take advantage of opportunities. This development strategy is very well implemented, focusing on developing creative knowledge from human resources through training and matters relating to increasing creativity and growing an entrepreneurial spirit. And creativity in creative packaging industries and tourist destinations is in the form of 3 things: something to do, something to see, and something to buy (Nurchayati \& Ratnawati, 2016). This is also in line with Rini \& Czafrani's research (2010) that youth are the main force and actor in selling Indonesian cultural diversity, especially in the creative economy sector. Through this, it is hoped that young people can face the challenges of globalization by not losing their identity as Indonesian youth and succeeding in the global market.

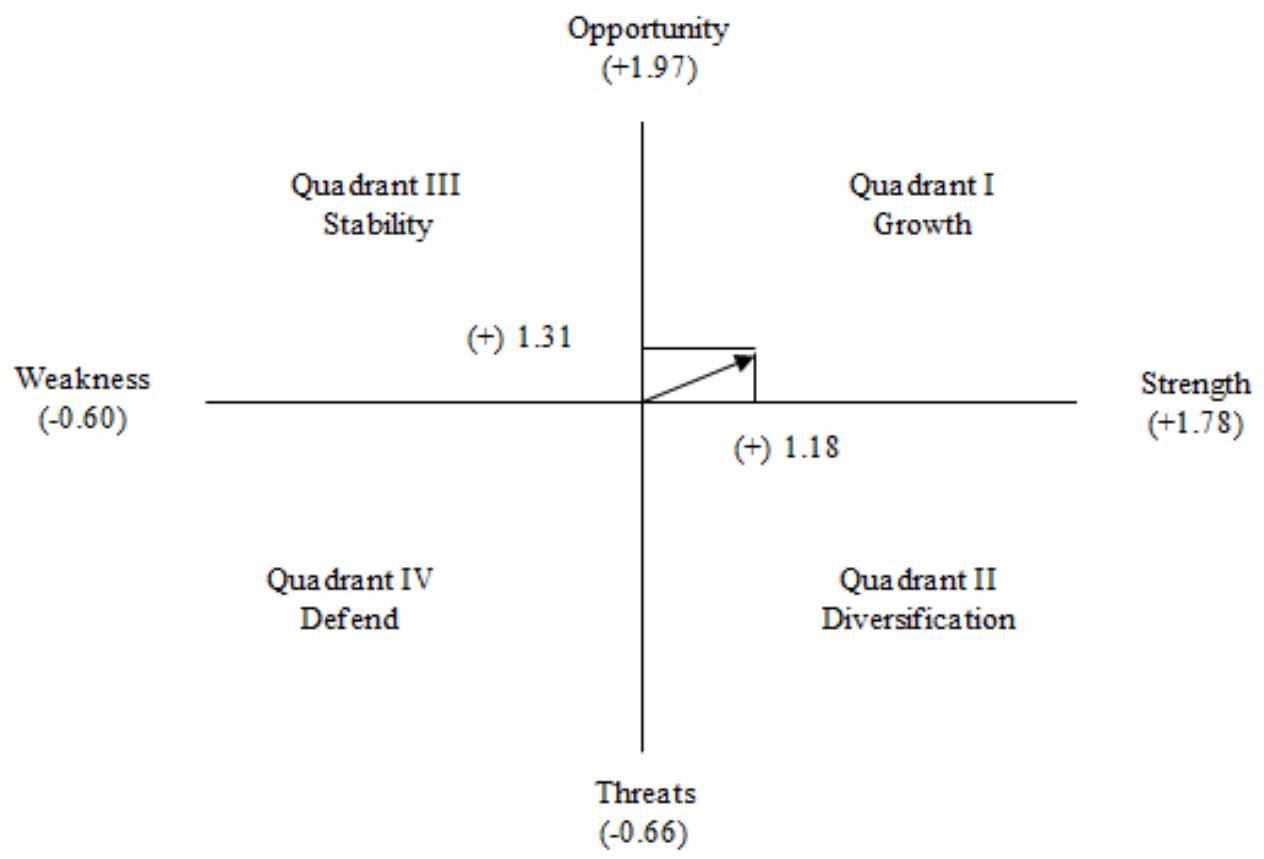

Figure 1. Cartesian diagram SWOT

This strategy is known as the term growth strategy. The implementation of SO strategy are:

1. Improving the quality of human resources to produce products in accordance with market demand.

2. Optimizing the utilization of information and communication technology

3. Improving cooperation between a creative economy with colleges

4. Increasing cooperation between creative economy. 
5. Creating quality products and competitiveness of existing natural resources to gain wide market share in the ASEAN market.

Jodi et al. (2019), the creative industry sector is unique because it relies on human resources' creativity and innovation power in the production process. This finding is consistent with Hesty \& Indra (2020), which, in addition to prioritized human resources, must increase the availability of potential resources and partnerships and control market changes quickly.

\section{CONCLUSIONS AND RECOMMENDATIONS}

\section{Conclusions}

All sub-sectors of the creative economy have advantages. Crafts and culinary are the two most superior creative economy sub-sectors. Based on the Cartesian SWOT diagram, the creative economy sector is in the first quadrant. The creative economy development strategy is an SO strategy, which is a strategy to use all strengths to take advantage of opportunities. For the development of the creative economy in Indonesia, this leading sector must receive serious attention from the government. facilitate access to capital, improve the quality of human resources in the creative economy, ease of market access, and ease of regulation, so that it is hoped that the creative economy can become the backbone of the Indonesian economy

\section{Recommendations}

The government must play a major role and cooperate with relevant agencies and creative economy actors in developing the creative economy. Creative economy development aims to improve the quality of human resources by utilizing Indonesia's natural resources to create quality and competitive products.

Indonesia's creative economy must have wider export destinations than before. So far, Indonesia's creative economy export destinations are more focused on the Malaysian and Singaporean markets.

Based on the analysis of RCA, AR, and ECI that those who meet the three criteria are culinary and crafts, the development of these sub-sectors must be further improved in terms of product quality, price, raw materials, and quality packaging so that the subsector continues to be competitive with foreign products and able to seize the ASEAN market

\section{REFERENCES}

Adelakun, J.O \& Olayiwola, O.K. (2020). Econometric Analysis of Export Led Growth in the Nigerian Economy. Journal of Economics and Management Science, 3(2), $38-46$

Agung, A. (2014). Creative Economy: National Architectural Development Plan 20152019. Jakarta: PT. Czech Solution.

Akter, M. \& Bulbul, M.N. (2017). Comparative Analysis Between Export-Led Growth and Import-Led Growth: A Study on Developing Eight (D-8). International Journal of Economics Finance and Management Sciences, 5(4), 204-2012

Amalia, P. \& Firdaus, M. (2014), Posisi Daya Saing Dan Faktor-Faktor Yang Memengaruhi Ekspor Buah-Buahan Indonesia, Jurnal Manajemen dan Agribisnis, 11(2), 129-143

Athanasia S.K. \& Trevor W.C. (2020) Merchandise exports and economic growth: multivariate time series analysis for the United Arab Emirates. Journal of Applied Economics, 23(1), 163 - 182 
BEKRAF \& BPS. (2017). Buku 2 Penyusunan Laporan dan Ekspor PDB Ekonomi Kreatif 2010-2015 Retrieved from http://www.bekraf.go.id.

BEKRAF. (2020). Perkembangan Ekonomi Kreatif di Indonesia. Retrieved from http://www.bekraf.go.id/profil

BPS. (2016). Statistik Indonesia 2016. BPS: Jakarta

Dellyana, D., Hadiansyah, F., Hidayat, A. \& Asmoro, W. (2015). Ekonomi Kreatif: Rencana Pengembangan Industri Musik Nasional 2015-2019. Jakarta: PT. Republik Solusi ,.

Greenaway, S., Dhine, R.C. \& Wright,P. (1999). An empirical assessment of the impact of trade on employment in the United Kingdom. European Journal of Political Economy, 15(3), 485-500

Haryadi, H. (2014). Ekonomi Internasional, Teori dan Aplikasi. Bogor: Biografika.

Herzer, D. (2010). A further examination of the export-led growth hypothesis. [IAI Discussion Papers, No. 200], Georg-August-Universität Göttingen, IberoAmerica Institute for Economic Research (IAI), Göttingen

Hesty, A. \& Indra, I. (2020). Strategi Pengembangan Industri Kreatif Untuk Inovasi. Jurnal Teknologi Industri Pertanian. 30(3),290-298.

Howkins, J. (2001). The Creative Economy. How people make money from ideas. London: The Penguin Press

Ibrahim, M.H. \& Abdalla, A.M.A. (2020). Export-Led Growth Hypothesis: Empirical Evidence From Sudan. International Journal Of Business Management And Economic Research, 11(2), 1717-172

Jodi, N.S., Sudjadi, A. \& Anggraeni, A.I. (2019). The role of creativity in forming innovative behaviours of creative industrial workers. International Journal Innovation, Creativity and Change, 11(9), 166-178.

Kim, B., Kyophilavong, P., Nozaki, K., \& Charoenrat, T. (2020). Does the Export-led Growth Hypothesis Hold for Myanmar? Global Business Review. https://doi.org/10.1177/0972150919863929

Kollie, G.B. (2020).Export-Led Growth Hypothesis in ECOWAS: A Panel Data Analysis. African Journal of Economic Review, 8(2), 258 - 275

Lestariningsih, E., Gusnisa, S. \& Maharani K. (2017). Legal setting for the development of interagency sectoral statistics database (ISSD). Paper presented at Asia-Pacific Economics Statistics Week, 22 - 26 May 2017. Jakarta: BPS

Muslim, C. (2006). Analisis Daya Saing Produk Ekspor Agroindustri Komoditas Berbasis Kelapa di Indonesia. [ICASEPS Working Paper, No.87]. Jakarta:Pusat Analisis Sosial Ekonomi dan Kebijakan Pertanian, Badan Penelitian \& Pengembangan Pertanian, Departemen Pertanian

Nurchayati, N. \& Ratnawati, A.T. (2016). Strategi Pengembangan Industri Kreatif Sebagai Penggerak Destinasi Pariwisata Di Kabupaten Semarang. Prosiding Seminar Nasional Multidisiplin Ilmu. Semarang: UNISMA

Nushiwat, M. (2008). Exports And Economic Growth A Re-Examination Of The Causality Relation In Six Countries, 1981-2005. Applied Econometrics And International Development, 8(2), 5-12

Polnaya, G.A. \& Darwanto, D. (2015). Pengembangan Ekonomi Lokal untuk Meningkatkan Daya Saing pada UKM ekonomi kreatif Batik Bakaran di Pati, Jawa Tengah, Journal of Business and Economics. 22(1), 1 - 10

Porter, M.E., \& Ramirez-Vallejo, J. (2017). Walmart: Navigating a changing retail landscape. Case study. Boston: Harvard Business Publishing

Purnamasari, M., Hanani, N. \& Huang, W.C. (2014). The competitiveness analysis of indonesian coffee export in the world market). Agrise 14(1), 58-66

Purwanto, P. (2008). Metodologi Penelitian Kuantitatif. Yogyakarta: Pustaka Pelajar 
Rambatan, G.B. (2015). Ekonomi Kreatif: Rencana Pengembangan Penerbitan Nasional 2015-2019. Jakarta: PT Republik Solution

Rangkuti, F. (2016). SWOT Balanced Scorecard: Develop Technique Effective Corporate Strategy plus How To Manage Risk and Performance. Jakarta: PT. Gramedia Pustaka Utama.

Rangkuti, F. (2019). Teknik Membedah Kasus Bisnis Analisis SWOT: Cara Perhitungan Bobot, Rating dan OCAI. Jakarta : PT. Gramedia Pustaka Utama.

Rini, P. \& Czafrani, S. (2010). Pengembangan Ekonomi Kreatif Berbasis Kearifan Lokal Oleh Pemuda Dalam Rangka Menjawab Tantangan Ekonomi Global. Jurnal UI Untuk Bangsa Seri Sosial dan Humaniora, 1, 12-24.

Romarina, A. (2016). Economic Resilience pada Industri Kreatif Guna Menghadapi Globalisasi dalam Rangka Ketahanan Nasional. Jurnal Ilmu Sosial, 15(1), 35-52

Rosnawintang, R., Suwandi, S. \& Asizah, N. (2015). Analisis Daya Saing Dan Strategi Industri Makanan Dan Minuman indonesia Di Era Masyarakat Ekonomi Asean. Jurnal Ekonomi Pembangunan, 5(2), 20-28.

Salvatore, D. (2014). International Economics. Jakarta: Salemba Empat.

Sannassee, R.V., Seetanah, B. \& Lamport, M.J. (2014) Export Diversification and Economic Growth: The Case of Mauritius. In: Jansen, M., Jallab, M.S. and Smeets, M., Eds., Connecting to Global Markets-Challenges and Opportunities: Case Studies Presented by WTO Chair-Holders, Chapter 1, WTO, Geneva, 11-23. Retrieved from: http://www.wto.org/english/res_e/booksp_e/cmark_full_e.p

Subagja, I.K. (2017). Creative industry competitiveness in Indonesia. International Journal of Academic Research and Development, 2(5), 428-439

Sumiati, M. (2015). Gerabah Lombok Diekspor Lewat Bali. Retrieved from https://medanbisnisdaily.com/news/read/2015/10/23/193964/gerabah_lombok_die kspor_lewat_bali/.

Syarif, M., Azizah, A. \& Priyatna, A. (2015). Analisis Perkembangan Dan Peran Industri Kreatif Untuk Menghadapi Tantangan MEA 2015. Prosiding Seminar Nasional Inovasi dan Tren (SNIT) B-27

Zuhdi, F., \& Suharno, S. (2016). Analisis Daya Saing Ekspor Kopi Indonesia dan Vietnam di Pasar ASEAN 5. Habitat, 26(3), 152-162. 